\title{
Gastric Cancer pT1 TNM Finding v8
}

National Cancer Institute

\section{Source}

National Cancer Institute. Gastric Cancer pT1 TNM Finding V8. NCI Thesaurus. Code C133609.

Gastric cancer with tumor invading the lamina propria, muscularis mucosae, or submucosa. (from AJCC 8th Ed.) 